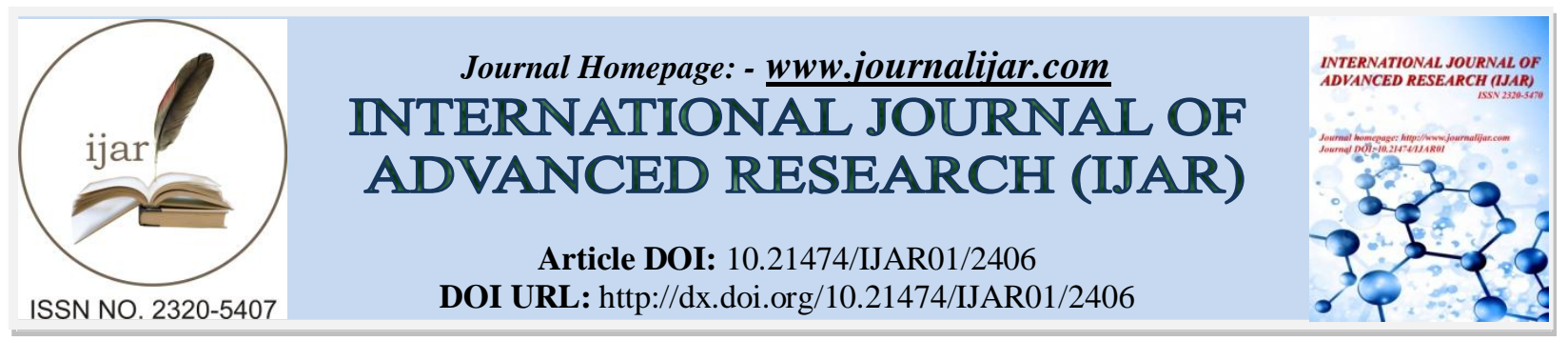

RESEARCH ARTICLE

VIRTUAL KEYBOARD.

\title{
INNOVATIVE TECHNOLOGIES IN THE EDUCATION PROCCES OF COMPETITIVE PROFESSIONALS.
}

\author{
Dmitry Lepeshev $^{1}$, Railya Mukhamadeyeva ${ }^{2}$ and Natalya Salikova ${ }^{3}$. \\ 1. Professor of Kokshetau Abay Myrzakhmetov University, Republic of Kazakhstan. \\ 2. Associate Professor Kokshetau Abay Myrzakhmetov University, Republic of Kazakhstan. \\ 3. Associate Professor Kokshetau Abay Myrzakhmetov University, Republic of Kazakhstan.
}

\section{Manuscript Info}

\section{Manuscript History}

Received: 19 October 2016

Final Accepted: 20 November 2016

Published: December 2016

\section{Key words:-}

innovation in technical education, additive technology, CAD systems, three-dimensional printing,

\section{Abstract}

This article describes material about necessity of implementation CAD systems in the education process. This is the first necessity for the introduction of additive technologies. Scientific novelty and practical importance of the research of additive technologies to Kazakhstan's obvious. First of all, is the creation of a new area of technological knowledge for industrial production. In addition to the economic efficiency of the implementation of additive technologies in production, it has a high social value. Additive technology - a completely new technology for Kazakhstan, for which there are no books and methodical recommendations.

Copy Right, IJAR, 2016,. All rights reserved.

\section{Introduction:-}

The key factor in the growth of any economy is to organize an effective system of technology transfer and its further improvement. To achieve stable economic growth through rapid industrialization - this words of president RK addresses to the nation. Integration of science with businesses plays an important role in the innovative development of the economy - the availability of information about demanded specialities, targeted training programs by enterprises orders, the establishment of regional training centers at universities, working(работоспособные) contacts with employment centers.

Over the past years, industries in Kazakhstan and in other CIS countries have undergone significant transformation. Enterprises have experienced entry into the market, reducing influence of the government in the economy, interruptiom of well-established cooperative relations, the disappearance of traditional channels and product markets, the appearance of more efficient foreign competitors, the process of change of ownership.

At the moment there is an active implementation in all areas of new equipment, working on additive technologies. Additive Fabrication (AF) or Additive Manufacturing (AM) denotes the additive, i.e. produced by the addition. This technology, based on a constant build of three-dimensional digital model obtained by modeling or scanning. (Mukhamadeyeva et al., 2016). 


\section{Review Articles:-}

Exclusivity of products is created on the first step of new technology at design stage. You must accurately present the subject of production and have it digitized three-dimensional model.

Existence of three-dimensional electronic model is sine qua for additive technologies.

The most important task is the comprehensive growth of labor productivity, and the technical equipment of modern industrial enterprise is closely connected with the computer aided design systems (CAD). The correct choice of software and supplier of CAD / CAE / CAM systems will have a direct influence on the production, the direction of development and its trends.

A sensation in the world of CAD was the issue of Russian freely distributed non-profit system of three-dimensional design KOMPAC-3D LT. This system is perfectly suited for the educational development works in various sectors of activity. It is targeted mainly at students of technical iniversities, technical schools and colleges who do a lot of graphic works for different subjects and allows you to organize a real two-stage work process, at the university computer labs we can use a professional version, and LT version on home computers.

COMPASS has been successfully used in more than 450 educational institutions in Russia, Ukraine, Kazakhstan and other CIS countries. Successful usage of the KOMPAC in education is largely due to the fact that the company ASCON has released a series of informational and educational manuals to special versions of their packages not only for students but also for pupils. This allows students to work with CAD-systems not only in the classrooms, but also on their home computers, so it became possible to speak not only about superficial knowledge of the software product but about real mastering. (Mukhamadeyeva, 2015a).

Computer-aided design system allows to mechanize the performance of flat drawings(плоские чертежи или 2D drawings) and technical drawings, but a three-dimensional solid modeling is one of the most exciting and promising areas of CAD. Widespread usage of 3D-graphics has already started in industry, including enterprises in Pavlodar, therefore, a demand arose for training specialists, possessing the technology of creating three-dimensional models(проверить).

Our industry is looking forward to a new generation of engineers. Requirements for products, market requirements, the requirements of international partners, all confirmed the necessity to maximize knowledge of information technology.

Rather complex situation exists in the production field, and in high school, when the old and experienced engineering staff doesn't possess progressive methods of computer design and production-support work(preproduction), and the young, adapted to innovative technologies do not have enough work experience. The only condition for maximum effect - is the identity of the information environment of engineer and student. Relevance of link between production and high school education has increased. Considering that a large part of cost (about 70\%) in the industry accounted for design and technological preparation of production, it must be admited that implementation of CAD systems has become an urgent necessity.

As of 2016 region there are many research organizations, among which five are educational institutions (universities and their affiliates). For a town with population of 130,000 - it is a very good indicator. This situation supposes a high level of competition in the education market and it contributes to increse quality of training specialists.

There are 10 departments in the private University named after Abai Myrzakhmetov, each has scientific student groups and clubs. University acquired the license of three-dimensional computer-aided design system KOMPAC. The reason for choice this software product is that COMPASS is used by leading machine-building enterprises of JSC " PMZ", a joint stock company " Tynys", which is part of the National Company "Kazakhstan Engineering" . JSC " Tynys" works closely with companies such as "NC" Kazakhstan Temir Joly " CNPC " Aktobe "," Kazakhtelecom "," Kazzinc "," Arcelor Mittal Temirtau "," Kazakhstan Aluminium "," Kazakhmys Corporation " " KazTransOil " "Ust -Kamenogorsk Titanium magnesium Plant " and others(проверить). In addition , the company is an active participant of foreign economic activity: production of the plant is successfully entering into near markets and far abroad. The company has a huge intellectual potential, highly skilled workers and professionals. Currently there are more than ten companies use software Compass in their in he Akmola region, four of them have acquired the professional version of the product . (Mukhamadeyeva, 2015b) 
Students of University mastering the technique of three-dimensional modeling can demonstrate the threedimensional image of any product on a flat screen. This is a powerful incentive for the creation better products. Foundation for the creative development of the future specialist is based, also it reduce time of routine work to create drawings.

With the implemention of CAD systems in the educational process, it has become necessary to improve teaching methods. New ways of organization forms and methods of teacher's work with students have appeared. Traditional classes with a large audience and note-taking students lost its meaning (for example on the subject " Descriptive Geometry "). Style of independent work also has changed . Free up time for additional material and providing private lessons for some special subjects . Students have the opportunity not only for self-study material, but also for self-evaluation. Now it is possible to fast or in-depth study of topics which are not included in the required course . With the necessity to move Kazakhstan economy from raw materials to service and technology, highly relevant is an implementation of computer aided design systems and development of techniques to create three-dimensional models into the educational process. CAD systems and speed up of production, including development work will be required to assist the creation of the technology-intensive industrial sector in the Republic. Correspondence with international standards in the industry and in education will create the conditions for successful entry of Kazakhstan into the world market and its participation in the international division of labor.

3D-print today is no longer innovation it turns into usual business and KOMPAS-3D becomes habitual tool for many users. (Mukhamad. et al., 2016d)

The main advantages of software are:

- Russian, very simple interface that gives you a clear advantage over foreign design systems, it contributes to the rapid training of working in the program, even who first sat down at the computer;

- Ease of use;

- The availability of teaching materials and methodological literature that is available and distributed free of charge;

- A two-level training (freeware version for non-commercial home computers and licensed version);

- Universality (for machine-building, instrument-making, construction and other.

According to results of analysis these activities in the Republic of Kazakhstan, we can say that existing information about additive technologies represents by a number of controversial proposals without adequate scientific and engineering work. (Mukhamadeyeva. 2016c)

Complexity of the process, absence of a mathematical model, which would enable to calculate characteristics of three-dimensional printing with needed accuracy, such as shrinkage, deformation, force, contact pressure, etc. It allows us to speak about insufficient degree of researches into new technologies.

Additive technologies have great potential in reducing energy expenses for creation wide variety of products. Level of using AM-technologies in production of goods is a faithful indicator of real industrial situation it isindicator of its innovative development.

\section{References:-}

1. Muhamadeyeva R. M. (2013): Technology transfer is prototyping in Kazakhstan. European Applied Sciences. 5:. $15-17$

2. Muhamadeeva R. M. (2014):. Parameters of additive technology at the 3D printing. The International scientific and practical "Europe-Asia" conference. 4:. 118-119

3. Muhamadeyeva R. M., Muhamadeyeva T. M., Muhamadeyeva I. A. (2015):. Structural and Logical Approach to the Introduction of Dual Training in Vocational and Technical Education System of the Republic of Kazakhstan. Indian Journal of Science and Technology, 8(S10):. 239-246

4. Muhamadeeva R. M., Nazarenko M., Okselenko O., Abayeva N. F., Golovachyova V. N., Baidak Y. (2016):. Innovations in technical and natural science. East West:. 42-56

5. Muhamadeeva R. M., Muhamadeyeva T. M., Muhamadeyeva I. A. (2016):. Implementation issues of additive technologies. International journal of engineering sciences \& research technology. 5(2):. 554-568

6. Muhamadeeva R. M. (2016):. Research and development of additive technology in industrial manufacturing of new products in Kazakhstan. International Journal of Engineering Research and Generic Science.2 (5):. 19 - 28 